Published Chapter. Please cite as:

Jarzabkowski, P., Matthiesen, J.K., \& A. Van de Ven. 2009. 'Doing which work? A practice approach to institutional pluralism.' In Lawrence T., Leca, B. and $\mathbf{R}$.

Suddaby. (Eds) Institutional Work: Actors and Agency in Institutional Studies of Organizations. Cambridge, UK: Cambridge University Press

Doing Which Work? A Practice Approach to Institutional Pluralism

\author{
Authors \\ Paula Jarzabkowski* \\ Jane Matthiesen* \\ Andrew Van de Ven** \\ * Aston Business School, Aston U, Birmingham \\ ** Carlson School of Management, Minnesota U, Minnesota
}

Contact author:

Paula Jarzabkowski

P.A.Jarzabkowski@aston.ac.uk

Tel: +44 (0)121 2043139 
Jarzabkowski, P., Matthiesen, J.K., \& A. Van de Ven. 2009. 'Doing which work? A practice approach to institutional pluralism.' In Lawrence T., Leca, B. and R. Suddaby. (Eds) Institutional Work: Actors and Agency in Institutional Studies of Organizations. Cambridge, UK: Cambridge University Press

\section{Doing Which Work? A Practice Approach to Institutional Pluralism}

This chapter takes a social theory of practice approach to examining institutional work; that is, how institutions are created, maintained and disrupted through the actions, interactions and negotiations of multiple actors. We examine alternative approaches that organizations use to deal with institutional pluralism based on a longitudinal real-time case study of a utility company grappling with opposing market and regulatory logics over time. These two logics required the firm to both mitigate its significant market power and also maintain its commercially competitive focus and responsiveness to shareholders.

Institutional theorists have long acknowledged that institutions have a central logic (Friedland and Alford, 1991) or rationality (DiMaggio and Powell, 1983; Scott, 1995; Townley, 2002), comprising a set of material and symbolic practices and organizing principles that provide logics of action for organizations and individuals, who then reproduce the institutions through their actions (Glynn and Lounsbury, 2005; Suddaby and Greenwood, 2005). Despite a monolithic feel to much institutional theory, in which a dominant institutional logic appears to prevail, institutional theorists also acknowledge a plurality of institutions (e.g. Friedland and Alford, 1991; Kraatz and Block, 2007; Lounsbury, 2007; Meyer and Rowan, 1977; Whittington, 1992). While these pluralistic institutions may be interdependent, they are not considered to co-exist in harmony; "There is no question but that many competing and inconsistent logics exist in modern society" (Scott, 1995: 130).

Pluralistic institutions are thus a source of contradictory logics (e.g. Friedland and Alford, 1991; Meyer and Rowan; Seo and Creed, 2002; Townley, 2002), which are expected to generate conflict, contradiction or confusion for organizations and individuals as they seek to realize these logics in action. Kraatz and Block (2007) define this condition as institutional pluralism; organizations operate in multiple institutional spheres, each of which provides different logics that play out in the organization as persistent and deep-rooted tensions. 
Jarzabkowski, P., Matthiesen, J.K., \& A. Van de Ven. 2009. 'Doing which work? A practice approach to institutional pluralism.' In Lawrence T., Leca, B. and R. Suddaby. (Eds) Institutional Work: Actors and Agency in Institutional Studies of Organizations. Cambridge, UK: Cambridge University Press

Pluralism arises from the presence of divergent interest groups, each of which has sufficient power to ensure that their interests remain legitimate (Lindblom, 1965). In pluralistic contexts, divergent interests are neither reconcilable nor able to be suppressed; they must co-exist (Denis et al, 2007; Hardy, 1991; Kraatz and Block, 2007; Jarzabkowski and Fenton, 2006). Institutional pluralism thus represents a significant set of organizational challenges. Pluralistic situations entail the co-existence of alternative, legitimate and potentially competing strategies within a single organization. These situations are contrary to management principles of consensus, unity of command, and structural alignment to a singular vision. Moreover, pluralistic groups are interdependent. They must interact and accommodate each others' interests in creating negotiated orders through partisan mutual adjustments (Van de Ven, 1999). However, the practice of coping with pluralistic institutions within an organization has received very little empirical study to date (Denis et al, 2007; Kraatz and Block, 2007). Consistent with the under-researched and dynamic nature of the phenomena, we undertook this study to examine how organizations and the actors within them cope with institutional pluralism over time?

\section{CONCEPTUAL BACKGROUND}

Institutional pluralism has been examined in institutional theory primarily at the field level. For example, it has been used to explain variation in diffusion of institutionalized practices. Different logics provide viable alternatives that account for practice variation in firms within the same industry (e.g. Hung and Whittington, 1997; Lounsbury, 2007). Other studies examine institutional pluralism as a source of institutional change, either through substitution, in which an existing institutional logic is replaced by a new, competing logic or by sedimentation, in which new logics layer over and add new meaning to existing logics (e.g. Cooper et al, 1996; Zilber, 2006), sometimes resulting in one suppressed and one dominant logic (e.g. Reay and Hinings, 2005; Townley, 2002). Competing logics might also engage in a 
Jarzabkowski, P., Matthiesen, J.K., \& A. Van de Ven. 2009. 'Doing which work? A practice approach to institutional pluralism.' In Lawrence T., Leca, B. and R. Suddaby. (Eds) Institutional Work: Actors and Agency in Institutional Studies of Organizations. Cambridge, UK: Cambridge University Press

dialectic of opposition which can be reconciled through synthesis of the two. Synthesis is typically achieved through conflict between logics, which provides opportunity for political action as disaffected actors draw upon pluralistic tensions to motivate change (e.g. Greenwood and Hinings, 1996; Hargraves and Van de Ven; 2006; Seo and Creed, 2002; Suddaby and Greenwood, 2005; Van de Ven and Hargraves, 2004). While these field level studies acknowledge institutional pluralism, they tend to avoid the issue of ongoing coexistence between logics, assuming instead institutional change arising from pluralism. They thus fail to illuminate how different logics co-exist inside the organization, which is a key issue for understanding how organizations and their actors cope with institutional pluralism (Denis et al, 2007; Jarzabkowski and Fenton, 2006; Kraatz and Block, 2007). We thus look to alternative explanations in order to understand how organizations and actors cope with ongoing tensions occasioned by managing coexisting, pluralistic interests.

Kraatz and Block (2007) propose that institutional pluralism should be studied at the level of the organization and its actors. Institutional pluralism thus lends itself to a growing interest in institutional work. Building from concepts of agency within institutional theory (e.g. Barley and Tolbert, 1997; Hargraves and Van de Ven, 2006; Jefferson, 1991; Oliver, 1991), Lawrence and Suddaby (2006) propose that the taken-for-granted presence of institutions is over-emphasized, such that their emergence, instantiation and change within the everyday practices of organizations and their actors is inadequately explained. They develop a research agenda on institutional work, studying how organizations and individuals create, maintain and disrupt institutions (Lawrence and Suddaby, 2007). This research agenda, which aligns with the level of analysis of our research question, is explained in the introductory chapter to this book. Rather than restating the premises of each category of institutional work, we now consider their implications for coping with institutional pluralism. 
Jarzabkowski, P., Matthiesen, J.K., \& A. Van de Ven. 2009. 'Doing which work? A practice approach to institutional pluralism.' In Lawrence T., Leca, B. and R. Suddaby. (Eds) Institutional Work: Actors and Agency in Institutional Studies of Organizations. Cambridge, UK: Cambridge University Press

Institutional creation examines how new institutions emerge and become established. Lawrence and Suddaby (2007) suggest three main types of work associated with creating institutions, political work, reconfiguring belief systems and altering meaning system boundaries, each of which might involve different types of practices. The premises of institutional creation furnish some insight into institutional pluralism, in terms of explaining how a new institution is created and inserted into an existing set of institutions. In particular, political practices might be important in ensuring that a new institution can survive within the contested and competing environment of institutional pluralism. We thus suspect that this type of institutional work will be relevant to a study of institutional pluralism. However, it is not clear how the created institution coexists with other institutions that may threaten it. The implicit assumption is that these created institutions will replace or reframe existing institutions by reconfiguring belief systems and altering meaning boundaries. Further empirical research is necessary to examine whether and how these types of work and practices associated with creating new institutions play out in the context of institutional pluralism.

Maintenance, the second category of institutional work identified by Lawrence and Suddaby (2007), examines how institutions are actively produced and reproduced through everyday practice. As the authors note, institutional maintenance is a taken-for-granted premise of institutional theory - institutions persist - yet how such institutions continue to persist is a neglected topic (Scott, 2001). Two main types of institutional work associated with institutional maintenance are adhering to rule systems and reproducing norms and belief systems. The concept of institutional maintenance is particularly pertinent to a study of institutional pluralism. When multiple, potentially contradictory logics coexist, it seems that any particular institution must continuously be maintained, in order to avoid being dominated by other competing logics. Indeed, Lawrence and Suddaby (2007) suggest that institutional maintenance will be more evident during times of upheaval or threat, when actors must 
Jarzabkowski, P., Matthiesen, J.K., \& A. Van de Ven. 2009. 'Doing which work? A practice approach to institutional pluralism.' In Lawrence T., Leca, B. and R. Suddaby. (Eds) Institutional Work: Actors and Agency in Institutional Studies of Organizations. Cambridge, UK: Cambridge University Press

actively preserve the existing institution. We therefore propose that the context of institutional pluralism provides an ideal research setting in which to examine and elaborate the concept of institutional maintenance, as multiple, potentially competing institutions must be maintained in coexistence.

The final category of institutional work that Lawrence and Suddaby (2007) explore is institutional disruption. Institutional disruption occurs where existing institutions do not meet the interests of actors who are able to mobilize sufficient support to attack or undermine these interests. Institutional disruption may thus be seen as a precursor or stage in the process of institutional change (e.g. Greenwood et al, 2002). Lawrence and Suddaby identify three institutional work practices focused upon undermining the prevalence of an existing institution: disconnecting rewards and sanctions from existing rule systems, procedures and technologies; disconnecting the moral foundations of particular norms; and undermining taken-for-granted assumptions. Institutional disruption is also pertinent to understanding institutional pluralism. For example, competing institutions may seek to disrupt each other. However, as each institution is legitimate and has the necessary resources to persist (Denis et al, 2007; Kraatz and Block, 2007; Lindblom, 1965), disruption will not be possible. As with institutional creation, there is an underlying assumption that disruption involves disrupting an existing institution in order to replace it with a new institution; pluralism is not incorporated sufficiently into the concept. We propose that institutional pluralism provides a context in which to elaborate the concept of institutional work associated with disruption.

Drawing upon the concepts of institutional work, we further developed our research question: "How do organizations and the actors within them engage in different types of institutional work as they endeavor to cope with institutional pluralism over time?" While it is premature to empirically 'test' the multiple categories put forward by Lawrence and Suddaby (2007), their concepts can usefully inform an exploratory study such as ours, with a view to 
Jarzabkowski, P., Matthiesen, J.K., \& A. Van de Ven. 2009. 'Doing which work? A practice approach to institutional pluralism.' In Lawrence T., Leca, B. and R. Suddaby. (Eds) Institutional Work: Actors and Agency in Institutional Studies of Organizations. Cambridge, UK: Cambridge University Press

elaborating some of these concepts and the associations between them. In particular, our focus upon institutional pluralism provides a critical context (Pettigrew, 1990) in which to observe actors within organizations actively engaged in institutional work.

\section{A Practice Approach}

Lawrence and Suddaby (2007) ground their interest in institutional work within a practice approach to institutions. The practice turn in social theory (Ortner, 1984; Reckwitz, 2002; Schatzki et al, 2001) has been adopted in a number of management and organization fields, such as technology (e.g. Barley, 1986; Orlikowski, 1992; 2000), accounting (Hopwood and Miller, 1994) and strategy (Jarzabkowski, 2004; 2005; Whittington, 2006). A practice approach examines how actors interact with, construct and draw upon the social and physical features of context in the everyday activities that constitute practice. Practice theorists address the duality of institutions and action; how institutions are constructed by and, in turn, construct action (e.g. Bourdieu, 1990; Giddens, 1984; Sztompka, 1991; Turner, 1994). While this is also a concern of institutional theory, particularly neo-institutionalists with their interest in instating agency in explanations of institutional change (e.g. Jefferson, 1991; Oliver, 1991; Seo and Creed, 2002), practice scholars take the actions, interactions and negotiations between multiple actors as their core level of analysis (Jarzabkowski et al, 2007). In these actions and interactions actors instantiate, reproduce and modify institutionalized practices through habit, tacit knowledge, culture, routines, motivations and emotions (Reckwitz, 2002).

A practice approach is apposite to a study of the institutional work because it focuses upon the actions and interactions of actors in creating, maintaining and disrupting institutions. Furthermore, it hones the level of analysis onto the everyday work of actors and how this work is shaped by institutions, even as it reproduces or modifies those institutions. It has particular value in studying the institutional work involved in institutional pluralism, as it 
Jarzabkowski, P., Matthiesen, J.K., \& A. Van de Ven. 2009. 'Doing which work? A practice approach to institutional pluralism.' In Lawrence T., Leca, B. and R. Suddaby. (Eds) Institutional Work: Actors and Agency in Institutional Studies of Organizations. Cambridge, UK: Cambridge University Press

shows how actors go about producing pluralistic institutions within their work, and coping with the tensions between these institutions through their actions and interactions. A practice approach acknowledges that the tensions of institutional pluralism may be part of the ordinary, everyday nature of work, rather than exceptional phenomena. It thus provides deep insights into the institutional work involved in coping with institutional pluralism.

As its name implies, practice theory is concerned with studying praxis (Jarzabkowski et al, 2007; Whittington, 2006). In praxis, actors are knowledgeable agents who construct and reconstruct institutionalized social structures with recognition of the limits and potentials of the current social order (Benson, 1977; Bourdieu, 1990; Giddens, 1984; Seo and Creed, 2002; Sztompka, 1991; Whittington, 2006). While various theoretical bases of praxis might be considered, this paper will draw upon Sztompka's (1991) theory of social becoming, on the basis that it goes beyond criticisms about the synchronic representations of agent and institutional structure present in structuration theory (Archer, 1995; Barley and Tolbert, 1997), the predisposition towards structural reproduction in habitus (Bohman, 1999; Turner, 1994), or the temporal separation of action and structure present in Archer's (1995) portrayal of realist theory (Clark, 2000).

Sztompka (1991) proposes that praxis is a unified "socio-individual field in the process of becoming" (p. 95). In the theory of social becoming, institutional structures are continuously being operationalized and actors are being mobilized within an ongoing stream of interactions. This stream of interactions is praxis; the nexus of "what is going on in a society and what people are doing" (ibid: 96, see also Child, 1997; Jarzabkowski, 2004; Whittington, 2006). From this perspective, concepts such as stability and change and structure and action are false representations of a social world that is continuously unfolding. Rather, social order is an ongoing process of "reweaving of actors" webs of beliefs and habits of action to accommodate new experiences obtained through interactions" (Tsoukas and Chia, 
Jarzabkowski, P., Matthiesen, J.K., \& A. Van de Ven. 2009. 'Doing which work? A practice approach to institutional pluralism.' In Lawrence T., Leca, B. and R. Suddaby. (Eds) Institutional Work: Actors and Agency in Institutional Studies of Organizations. Cambridge, UK: Cambridge University Press

2002: 567). Praxis is thus a helpful concept in examining how organizations and their actors construct and reconstruct institutional logics within their work practices over time. We focus upon praxis as the level of analysis in this paper, examining how actors instantiate the pluralistic institutional logics in which their organization is embedded through their ongoing interactions over time.

\section{RESEARCH DESIGN}

In keeping with the exploratory nature of our topic, we adopted a longitudinal, realtime, case-based approach (Pettigrew, 1992; Yin, 1994). Many utilities in essential industries, such as energy, telecommunications and water, are subject to economic regulation. These firms are typically former state-owned incumbents which, following privatization, have come to competitive markets with a historic legacy of assets and scale of resources that constitute barriers to entry for other industry players. Most notably, former incumbents are afforded significant market power because of their ownership of the distribution network upon which the industry is dependent.

Our research context is a listed utility company coping with the institutional pluralism that arises when market logic is confronted by regulatory logic ${ }^{1}$. The regulatory logic is to ensure a competitive market, in which one player, despite holding a key part of the value chain, is not able to maximize value from that asset through a monopoly (Kay, 2000). This logic is contrary to a free market logic, in which a publicly listed company has an obligation to make profit (Friedman, 1970). Under free market logic a firm would typically maximize a dominant market position arising from an integrated value chain (Porter, 1980; 1985). Regulated firms are thus beset by institutional pluralism (Sharratt et al, 2007), facing both a market logic of maximizing competitive position and, as listed companies, a strong

\footnotetext{
1 This problem is different from the extant work on institutional pluralism conducted in public sector, professional and cultural organizations in which a professional, value-based logic is confronted by a market logic (e.g. Glynn and Lounsbury, 2005; Oakes et al, 1998; Townley, 2002).
} 
Jarzabkowski, P., Matthiesen, J.K., \& A. Van de Ven. 2009. 'Doing which work? A practice approach to institutional pluralism.' In Lawrence T., Leca, B. and R. Suddaby. (Eds) Institutional Work: Actors and Agency in Institutional Studies of Organizations. Cambridge, UK: Cambridge University Press

commercial incentive to maintain this logic, and a regulatory logic that requires them to mitigate the advantages afforded by significant market power. We explore our research question in Utilco ${ }^{2}$, a regulated firm coping with these features of institutional pluralism.

As part of an increasing political drive to correct market imbalances in the sector, an agreement was reached between Utilco and the Regulator that Utilco would implement a new Regulatory Framework based on equivalence. Equivalence required Utilco to place its distribution networks within a separate transparent business division. While this new division, 'Distribution Division' (DD), would remain under the corporate Utilco structure, it would operate independently and provide equal access to the distribution networks to all industry players without favoring downstream Utilco businesses. A critical aspect of equivalence was that DD should not share any commercial information with downstream Utilco businesses or allow its decision-making to be affected by Utilco commercial objectives. Utilco would also have to separate all products it currently offered to the industry through its integrated value chain, so that these could be traded on a transparent market basis between the DD and Utilco's Retail Divisions (RDs).

Although this new Framework could not be considered a new institutional logic, it did represent a strengthening of the regulatory logic, containing strong coercive elements of legal redress if Utilco failed to meet the various legal deadlines (LID), which had been imposed to ensure timely compliance. In order to demonstrate that it fully embraced the strengthening regulatory logic, Utilco also volunteered some self-imposed deadlines (SID) for product separation, which were in advance of the LID and associated with substantial financial penalties if not met. At the LID, Utilco's RDs would be the only industry players required to use the equivalent product, although industry would take it up over the next 2-3 years.

\footnotetext{
${ }^{2}$ In order to preserve the anonymity of the case, all data that might reveal Utilco such as specific dates, names, products and other contextual features have been disguised. However, the nature and temporal sequence of events is faithfully reproduced.
} 
Jarzabkowski, P., Matthiesen, J.K., \& A. Van de Ven. 2009. 'Doing which work? A practice approach to institutional pluralism.' In Lawrence T., Leca, B. and R. Suddaby. (Eds) Institutional Work: Actors and Agency in Institutional Studies of Organizations. Cambridge, UK: Cambridge University Press

At the same time, Utilco was a competitive, publicly-listed company with a dominant position in the domestic-consumer market place and ambitions to further penetrate the highly competitive corporate-consumer market place. As such, Utilco had built its value proposition and competitiveness on the basis of superior customer service. A strengthened regulatory logic based on equivalence was thus seen as contradictory to the market logic; “...people aren't in business to be fair; they're in business to secure an advantage ..."

Longitudinal qualitative data were collected for an 18 month period, tracing the implementation of one of Utilco's major products, Product X, in real-time. Observations took place at the Corporate Centre (CC) and across each division of Utilco, including the regulated division Distribution Division (DD) and the Retail Divisions (RDs), comprising the two retail divisions, focused on either domestic and small-business customers (RD1) or corporate customers (RD2). The data collected included 69 fully transcribed open-ended interviews with key operational, middle and senior managers; notes and transcriptions based on nonparticipant observation of 184 audio-taped meetings across the divisions and at the corporate centre; complemented by additional informal observation and interaction, as well as documentary analysis. Together, these data amount to over 1,200 single-spaced A4 pages of data imported into NVivo for coding.

In order to make sense of the mass data, the authors wrote a rich chronological case story of the implementation of Product X from the perspective of the key groups - DD, RDs and CC (Langley, 1999). This story and its associated data was the basis of our analysis, comprising the unfolding interactions between actors over time as they attempted to cope with the pluralism occasioned by market and regulatory logic. Based on this story, we then identified the different logics being experienced in Utilco. As it is difficult to identify institutional logics empirically, we followed others in searching the raw data for indicators of the market and regulatory logics, such as evidence of norms, beliefs, values and work 
Jarzabkowski, P., Matthiesen, J.K., \& A. Van de Ven. 2009. 'Doing which work? A practice approach to institutional pluralism.' In Lawrence T., Leca, B. and R. Suddaby. (Eds) Institutional Work: Actors and Agency in Institutional Studies of Organizations. Cambridge, UK: Cambridge University Press

practices associated with each logic (e.g. Cooper et al, 1996; Scott et al, 2000; Reay and Hinings, 2005). Analysis identified and supported the existence of market and regulatory logics. Drawing upon the method used by Reay and Hinings (2005), Table 1 presents representative extracts of the raw data and our analysis of these data according to the belief systems, identified as those goals or values and actions to be pursued, that comprise each logic. A more complete report of this methodology can found in Jarzabkowski, Matthiesen \& Van de Ven (2008).

\section{INSERT TABLE 1 ABOUT HERE}

In particular we were looking for interaction between logics, any mutation of logics that might indicate a shift in their belief systems, or any synthesis or merging of logics. However, the logics remained intact and discrete throughout. Nonetheless, this analysis enabled us to decompose the case story into five distinct phases (Langley, 1999; Van de Ven, 1992), based on the process of Product X implementation and the practices that different groups in Utilco employed as they interacted with each other over Product $X$. These five phases will be presented in the results. Finally, we used Lawrence and Suddaby's (2007) categories of institutional work to inform our analysis of the phases. We looked specifically for evidence of work practices associated with institutional creation, maintenance and disruption, drawing upon Lawrence and Suddaby's (2007) concepts and subcategories to inform our coding judgments. These categories are now used in presenting the results of our analysis over 5 phases of implementing Product X.

\section{FINDINGS $^{3}$}

\section{Phase 1 (Months 1-4): The Regulatory Logic is Asserted \& Market Logic Disrupted}

\footnotetext{
${ }^{3}$ A comprehensive report on the data and results, including a more detailed description of the analysis process, can be found in Jarzabkowski, Matthiesen \& Van de Ven (2008)
} 
Jarzabkowski, P., Matthiesen, J.K., \& A. Van de Ven. 2009. 'Doing which work? A practice approach to institutional pluralism.' In Lawrence T., Leca, B. and R. Suddaby. (Eds) Institutional Work: Actors and Agency in Institutional Studies of Organizations. Cambridge, UK: Cambridge University Press

At the outset, Utilco CC was keen to prove itself fully committed to the new Framework. As part of the Framework agreement, the Distribution Division was physically separated from the Retail Divisions, being placed in a separate building, with new name, logo and access codes. This physical separation inhibited spontaneous interaction between parts of the business and emphasized the new ideals of equivalence in dealing with downstream Utilco divisions. Physical separation thus created the regulatory logic and, in doing so, disrupted the market logic by disconnecting existing practices of interaction between upstream and downstream businesses. DD was given a separate, independent status within Utilco that began the process of reconfiguring potential value chain advantages to RDs.

For the first couple of months, DD and RD worked on the separation of Product X in isolation from each other. RD activity was focused on attempting to develop systems to connect to the DD product, without being sure about the specification of the new DD product. DD activity was focused on the creation of their new boundaries, avoiding any interaction with RD because, under the norms of the regulatory logic, this would be improper conduct. DD insisted that RD should place any requirements for Product $\mathrm{X}$ through industry fora, which DD would incorporate only if they met the needs of the whole industry. RD was very worried by this behavior, as it was unable to gain any information on the Product it would be selling to its customers in 12 months time. In response, RD approached Utilco for support. However, RD had trouble gaining traction, as the dominant regulatory logic gave DD power to resist efforts to interact. DD's refusal to consider RD's needs for Product X further disrupted the market logic by undermining assumptions and beliefs about the importance of $\mathrm{RD}$ as a key DD customer.

Eventually in the third month, the two sides realized that they needed to discuss their parallel plans for Product X and meetings between the businesses were arranged. RD expressed its fears about the deterioration of customer service if product testing could not 
Jarzabkowski, P., Matthiesen, J.K., \& A. Van de Ven. 2009. 'Doing which work? A practice approach to institutional pluralism.' In Lawrence T., Leca, B. and R. Suddaby. (Eds) Institutional Work: Actors and Agency in Institutional Studies of Organizations. Cambridge, UK: Cambridge University Press

begin at least four months before the SID. A rift quickly became apparent, as RD's marketbased values and beliefs were dismissed by DD; “RD's expectation that the customer experience must NOT be compromised when disintegrating a vertically integrated company is living in cloud cuckoo land (DD Manager). Such assertions additionally disrupted the market logic by undermining the moral foundations of the Utilco value proposition, which was customer service. DD further advanced the regulatory logic by defining the interaction boundaries. DD emphasized that, under the new Framework, it must not be "unduly influenced" by RD in decision-making.

For RD, it was incomprehensible that the customer experience was being invalidated by DD. RD responded by actively maintaining the market logic, drawing on authority structures in an attempt to police and control DD behavior, whilst reaffirming its own belief in customer service as a central tenet of Utilco. The RD aim was to develop interlocked plans with DD that acknowledged the dependencies in developing a workable Product X. Otherwise the SID may not be met.

However, DD rejected this argument, refuting suggestions of interdependence and insisting that collaboration would counteract the regulatory logic; "They are not interlocked, interdependent plans. DD cannot be dependent on ...one industry player" (DD Manager). DD actively maintained the regulatory logic by adhering to its rule systems and insisting on independent work practices.

$\mathrm{CC}$ was keen to project a normative commitment to the new Framework and thus also maintained the regulatory logic by supporting DD's right to work independently. While the CC was already aware of problems with Product X, it was reluctant to shift the balance in favor of the market logic. It thus contributed to embedding the regulatory logic into everyday work practices and disrupting the market logic by suggesting that RD would need to find new 
Jarzabkowski, P., Matthiesen, J.K., \& A. Van de Ven. 2009. 'Doing which work? A practice approach to institutional pluralism.' In Lawrence T., Leca, B. and R. Suddaby. (Eds) Institutional Work: Actors and Agency in Institutional Studies of Organizations. Cambridge, UK: Cambridge University Press

work practices. Indeed, the Utilco CEO held a meeting with 350 key managers in Month 4, emphasizing that achieving the deadlines in the Framework was a priority for everyone.

\section{Phase 2 (Months 5-6): Incompatibility Between Logics Emerges}

Training about the types of information that could be shared under the Framework began to filter through, alleviating concerns about information-sharing between DD and downstream divisions. In addition, $\mathrm{CC}$ established an end-to-end management program for Product $\mathrm{X}$. These actions prioritized the regulatory logic but also attempted to alleviate frictions over the development of Product X.

While DD wanted to avoid undue influence, it agreed that there were interdependencies between the two units in meeting the SID. DD felt that it could cooperate with RD without compromising their regulatory values by changing its work practices in order to publish any Product X decisions and solutions to industry, as well as RD. DD thus actively maintained the regulatory logic; adhering to its rules about equivalence and embedding them within work practices that might also enable consideration of RD's position. RD used this as an opportunity to assert the market logic. It pointed out that a testing period of two months, at the barest minimum, was necessary in order to ensure that the Product would work for its customers.

Despite the resolve on both sides to try to work together, incompatibilities emerged, as DD's decision to publish everything to industry began to have consequences for Product X; "Apparently DD is now considering different Products because industry would like that but this is news to us" (RD Manager). The regulatory logic embedded within the DD work practices was incompatible with the market logic embedded in RD work practices; RD could not countenance building a Product X that jeopardized customer service. RD reinforced its own beliefs, stating that the new product spec had unacceptable service times and consequently asking DD to modify it. However, because of the regulatory logic embedded 
Jarzabkowski, P., Matthiesen, J.K., \& A. Van de Ven. 2009. 'Doing which work? A practice approach to institutional pluralism.' In Lawrence T., Leca, B. and R. Suddaby. (Eds) Institutional Work: Actors and Agency in Institutional Studies of Organizations. Cambridge, UK: Cambridge University Press

within its work practices, DD needed to check this modification with industry, delaying the response to RD. Misunderstandings accelerated and RD challenged DD's capacity as responsive supplier.

Feeling threatened, RD actively maintained the market logic by calling upon $\mathrm{CC}$ to impose deterrents upon DD and demanding that DD be held responsible for risk to market share occasioned by delays in customer service. As such, RD insisted that market-based values should be incorporated in the Product $\mathrm{X}$ design. RD also appealed to a higher power, the Utilco CEO, to increase visibility of service issues. Utilco CC was increasingly aware that there were problems with Product X, as rumors abounded that they may not meet the SID. CC responded by emphasizing deterrents to both sides if the SID was not met, in an attempt to balance the two logics. While this prioritized the SID as a normative regulatory objective, hence maintaining the regulatory logic, it did not pay attention to the complementary work practices necessary to achieve this objective.

\section{Phase 3 (Months 7-8): Polarization of Conflict Between Logics}

Conflict between the logics escalated as DD published its Product X spec, which RD had been awaiting, but it was neither what RD thought was agreed nor something capable of fulfilling their customer service needs. RD demonized DD, claiming that DD was using equivalence to bring the level of service down, rather than raising the service components of the product to industry as a whole. The CC end-to-end management program established a series of intensive but unsuccessful Product X inter-working sessions between the two divisions. RD would not consider a compromise to its market logic and adhered to its rule systems and beliefs, insisting that Product X should deliver their existing level of service; "There is little of a lower standard that RD could actually live with" (RD Manager). RD was angry that DD refused to acknowledge the inadequacies of Product $\mathrm{X}$ from a market perspective, and actively policed and criticized DD's behavior. For their part, DD managers 
Jarzabkowski, P., Matthiesen, J.K., \& A. Van de Ven. 2009. 'Doing which work? A practice approach to institutional pluralism.' In Lawrence T., Leca, B. and R. Suddaby. (Eds) Institutional Work: Actors and Agency in Institutional Studies of Organizations. Cambridge, UK: Cambridge University Press

refused to consider modifications to the Product X spec. They adhered to the regulatory rule systems, asserting that as long as a product was delivered by the SID, DD would have met its requirements, which were separate from Utilco requirements.

Power plays between the two divisions ensued. RD began to create its own version of the regulatory logic, defining DD as an industry supplier and insisting that DD should upgrade the standard of supply. At the same time, RD realized that it would have to raise prices to meet rising costs from the regulatory change, which inflamed its embedded market values. For DD, these RD problems were based on an obsolete market logic. DD disrupted market-based assumptions, suggesting that a level playing field would reduce RD service because its previous service constituted an unfair advantage. The situation on Product $\mathrm{X}$ arrived at a stalemate.

As CC became aware of escalating contradictions between the logics, it attempted to balance the two by inducing a focus on overarching Utilco aims and prioritizing the SID. However, it also recognized the contradictions in that message; "There is a problem with that because DD people are only allowed under the Framework to work to DD objectives, so it could constitute a breach to think of it that way for them, although the real breach will be if Utilco fails to meet the Framework" (CC Manager). Thus, by default, the CC maintained the regulatory logic without instituting work practices that would also enable the market logic.

\section{Phase 4 (Months 9-11): Creating logics in relation to each other}

In Month 9, a meeting between key managers from RD, DD and the Utilco CEO was held, at which RD asserted the importance of the market logic within Product X. The existing product from DD would enable them to meet the SID but in doing so would jeopardize customer service. The CEO insisted on adherence to both logics by insisting that the two sides must inter-work on Product X. The CEO of Utilco and the CEOs of the two divisions began 
Jarzabkowski, P., Matthiesen, J.K., \& A. Van de Ven. 2009. 'Doing which work? A practice approach to institutional pluralism.' In Lawrence T., Leca, B. and R. Suddaby. (Eds) Institutional Work: Actors and Agency in Institutional Studies of Organizations. Cambridge, UK: Cambridge University Press

weekly meetings with the key Product X players to enable and police the maintenance of both logics in hopes that they could still meet the SID with an acceptable product.

Both divisions were motivated to accommodate the other's position, reconfiguring their own belief systems in order to create the other's logic in relation to their own. Thus RD advocated tolerance of the industry consultation delays; "We've just got to learn that we've got to give DD headspace to develop things" (RD Manager), while DD tried to understand RD's service considerations with Product X; “DD call centre people will go into RD callcenters to see what the problems will be" (RD Manager). However, as DD attempted to accommodate the market logic, problems emerged that required it to also actively maintain adherence to the regulatory logic by continuing to check that Product $\mathrm{X}$ modifications were important for all of industry not solely RD.

RD also attempted to accommodate DD's need to consult industry by creating DD as an industry supplier and itself as an industry player. As all of industry would have to buy the same product, it could comply with both logics by lobbying industry and successfully gaining industry support for product specifications. RD was thus able to drive their market needs by defining the boundaries of the regulatory logic in relation to the market logic. DD was, however, worried about RD still having an undue influence, believing that these additional Product X services were only relevant to RD, which differentiated on customer service. Hence, industry probably would not purchase these services, so that DD would be developing Product X primarily for RD. DD self-policed its regulatory rule systems by undertaking a legal appraisal, which suggested that it might constitute a competitive advantage for RD. RD strongly disagreed with this interpretation, asserting its market-based rule systems; "this is something any scale operator would need of Product X" (RD Manager). RD engaged in its own policing, calling for arbitration from the CC. However, central arbitration was perceived 
Jarzabkowski, P., Matthiesen, J.K., \& A. Van de Ven. 2009. 'Doing which work? A practice approach to institutional pluralism.' In Lawrence T., Leca, B. and R. Suddaby. (Eds) Institutional Work: Actors and Agency in Institutional Studies of Organizations. Cambridge, UK: Cambridge University Press

as inappropriate, as DD adhered to its regulatory rules; "the Centre is not there to set commercial policy on DD products" (DD Manager).

Nonetheless, both sides attempted to accommodate the other, advocating tolerance of the other's position in relation to their own logic. RD accepted that DD was acting in good faith, while DD agreed it would not engage in a legal wrangle that could delay the LID, which was increasingly challenging. While both sides continued to inter-work, the logics persistently remained incompatible due to "the philosophical differences...that we're working to" (DD Manager).

Utilco CC found itself in the difficult position of explaining to the Regulator that it would not meet the SID. It began to create a space for the market logic within the regulatory logic, explaining that this delay was necessary to ensure that the industry remained sound and intact, avoiding a collapse in customer service arising from an unacceptable Product X. As a reasonable and responsive player, Utilco would prefer to pay the self-imposed fine than expose consumers to such risk. As RD was the largest industry player, the Regulator could be persuaded that it was important that Product $\mathrm{X}$ be serviceable for their large consumer base, especially as other industry players would also need to use the product at a later date. Utilco was thus able to maintain its commitment to the regulatory logic, whilst creating some room to adhere to their market logic of customer service, albeit at significant financial penalty.

\section{Phase 5 (Months 12-18): Mutual Adjustment between Logics}

Both divisions recognized the incompatibility between logics, as well as their operational interdependence in delivering Product X. Despite their interdependence, both sides continued to actively adhere to their own rule systems and assert their own beliefs. For example, enraged by delays in the DD release, $\mathrm{RD}$ responded by emphasizing the importance of customer service; "It fundamentally changes the operating model of RD. That is quite a major strategic impact. That would effectively lose the customer service differentiation point 
Jarzabkowski, P., Matthiesen, J.K., \& A. Van de Ven. 2009. 'Doing which work? A practice approach to institutional pluralism.' In Lawrence T., Leca, B. and R. Suddaby. (Eds) Institutional Work: Actors and Agency in Institutional Studies of Organizations. Cambridge, UK: Cambridge University Press

of RD strategy..." (RD Manager). DD disrupted the assumptions of market logic by suggesting a loss of customer experience to be the new norm: "Isn't that the point of equivalence?" (DD Manager).

Nonetheless, both sides increasingly maintained their own logic in relation to potential impacts from and upon the other logic. For example, DD acknowledged that its product did not meet the RDs' customer service expectations and tried to find alternative solutions, demonstrating a preparedness to police the incorporation of both logics within Product X. DD's willingness to acknowledge the market logic was made easier by RD's acknowledgement of the regulatory logic and its implications for its own work practices.

$\mathrm{CC}$ also actively began to enable the attainment of both logics within product $\mathrm{X}$, establishing specific work practices, including a weekly business-wide dashboard, at which differences could be dealt with quickly. This enabled the divisions to work around stalemates between the logics; "there is less and less emphasis of artificial boundaries... a degree of pragmatism is breaking through". However, inter-working also represented threats, such that each logic had also to be maintained, involving conscious self-policing and active embedding of existing logics in day-to-day work practices. DD emphasized its independence, while RD emphasized that it would only meet the regulatory implications of Product $\mathrm{X}$ within the parameters of their market logic, i.e. by achieving satisfactory customer service.

As the LID loomed, RD further embedded the market logic within its work practices, flagging up its fears that they could not meet the LID because of customer impact. RD labelled this impact as a "service crisis", thereby preserving the norms of customer service but also engaging in political work, deterring others from overriding the market logic because of pragmatic concerns to meet the LID; “The message 'a service crisis' is a political one. It sounds better to have a service crisis. No one will say "just get on with it"' (RD Manager). 
Jarzabkowski, P., Matthiesen, J.K., \& A. Van de Ven. 2009. 'Doing which work? A practice approach to institutional pluralism.' In Lawrence T., Leca, B. and R. Suddaby. (Eds) Institutional Work: Actors and Agency in Institutional Studies of Organizations. Cambridge, UK: Cambridge University Press

In the multiple inter-working meetings that had been established, the $\mathrm{CC}$ actively supported mutual adjustment between logics. While pragmatic considerations about interworking had increased as the deadline approached, this did not entail relaxation of either logic. Rather, each was actively maintained in relation to the other. For example, RD reproduced its existing norms "I appreciate the need to protect the customer experience, which is the basic tenant in...everything we do" (RD Manager) whilst also acknowledging that it could not enforce a suitable product for its needs because of the regulatory norms shaping DD practices.

The CC continued to confirm that both logics needed to be maintained, even though it realized this meant mutual adjustment and potential compromise between logics; "There can be no doubt where the CEO comes from. To reiterate - [the LID is] absolutely what we're aiming for, tempered by obviously continuing to look at the customer service position and ensuring that doesn't get any worse" (RD Manager).

At the LID, Product $\mathrm{X}$ was ready to use, albeit there being reservations about how well it could cope with customer requirements in the short-term. Utilco declared publicly that it had met the regulatory requirement of an equivalent Product X. However, at the same time in the external environment, it created a space for the market logic within its adherence to the regulatory logic by advocating the importance of customer service. For example, in its declaration it reserved the right to revert to its old, non-equivalent products temporarily, with financial penalties; “To minimize customer disruption, we are carefully monitoring and slowly increasing our use of ProductX...have the intention to use contingency systems if necessary to secure a high level of customer service. Given that Utilco reserves the right to use the existing fallback systems, we voluntarily prolong our payment to industry” (CC Manager).

\section{DISCUSSION}


Jarzabkowski, P., Matthiesen, J.K., \& A. Van de Ven. 2009. 'Doing which work? A practice approach to institutional pluralism.' In Lawrence T., Leca, B. and R. Suddaby. (Eds) Institutional Work: Actors and Agency in Institutional Studies of Organizations. Cambridge, UK: Cambridge University Press

This chapter set out to address the exploratory research question: "How do organizations and the actors within them engage in different types of institutional work as they endeavor to cope with institutional pluralism over time?" Table 2 summarizes the five phases of institutional work we found within the different groups over an 18 month period at Utilco. We now discuss these findings in terms of their contributions to our understanding of institutional pluralism and institutional work. The discussion is centered on five key findings.

\section{INSERT TABLE 2 ABOUT HERE}

In Phase 1, during the introduction of new regulatory measures, the divisions within Utilco actively engaged in all three types of institutional work. Disruption work was partially a facet of the strengthened regulatory framework, which created physical barriers between divisions that adhered to different logics. Such dramatic changes in work practices may be attributed to the state-conferred coercive power and legitimacy of regulatory institutions (Holm, 1995; Russo, 2001; Townley, 2002). Interestingly, these physical changes in the existing rule systems and rewards and sanctions also enabled DD to disrupt normative assumptions about the legitimacy and value of the market logic. By drawing on the legitimacy of the regulatory logic, they were able to make a virtue of their opposition to the market logic (Suchman, 1995). Similarly, CC, while not actively disrupting the market logic, also began to change normative assumptions by attributing regulatory rather than market-based meanings to RD's problems with the new order. Thus coercive mechanisms involved in disrupting the market logic were linked to more subtle disruptions to the moral foundations and assumptions underpinning that logic.

At the same time, DD engaged in creation work, defining the boundaries of what constituted 'proper' behaviors for actors acting within a regulatory logic. While it was not necessary to actually 'create' the regulatory logic, as it already had state and corporate parent legitimacy, political forms of creation work were part of the pluralistic context (Kraatz and 
Jarzabkowski, P., Matthiesen, J.K., \& A. Van de Ven. 2009. 'Doing which work? A practice approach to institutional pluralism.' In Lawrence T., Leca, B. and R. Suddaby. (Eds) Institutional Work: Actors and Agency in Institutional Studies of Organizations. Cambridge, UK: Cambridge University Press

Block, 2007). Creation work was a response to the embeddedness of the market logic, investing actions that opposed that logic with propriety. At the same time as creating the regulatory logic, both $\mathrm{DD}$ and the $\mathrm{CC}$ engaged in active maintenance work, adhering to rule systems that ensured DD's independence and embedding those rules within the DD belief systems, norms and work practices. DD was also active in self-policing, consciously adhering to its own rule systems whenever it felt compromised by its contact with actors working under market logic. RD was equally active in maintaining the market logic, as a response to the perceived threats of the regulatory logic, actively deterring regulatory influences upon its work and re-emphasizing its customer-service beliefs and norms. Summary Finding 1: Such conscious and active maintenance work by all parties, both in adhering to rule systems and also reproducing beliefs and norms, is associated with the perceived need to continuously fend off potential threat to an existing logic within a pluralistic context.

In Phase 2, the CC and DD ceased to actively disrupt the market logic or create the regulatory logic. However, they did not relax into taken-for-granted behavior but actively engaged in maintaining the regulatory logic, adhering to rule systems by self-policing and deterring perceived threats, as well as reinforcing the norms and beliefs embedded within independent work practices. At the same time, the RD actively maintained the market logic through emphasizing its norms and belief systems and actively deterring perceived regulatory threats. Thus, through the maintenance of their own logic within a pluralistic context, each side engaged in move and counter-move, perceiving maintenance acts by the other as oppositional and requiring active maintenance in response (Kraatz and Block, 2007; Lindblom, 1965). Summary Finding 2: Maintenance work within a pluralistic context may thus generate or at least support contradiction and conflict between opposing logics.

In Phase 3, maintenance of each logic was associated with escalation of conflict between logics and increasingly political forms of institutional work. As the actors in each 
Jarzabkowski, P., Matthiesen, J.K., \& A. Van de Ven. 2009. 'Doing which work? A practice approach to institutional pluralism.' In Lawrence T., Leca, B. and R. Suddaby. (Eds) Institutional Work: Actors and Agency in Institutional Studies of Organizations. Cambridge, UK: Cambridge University Press

division adhered to their own logic, actively maintaining their own rules, controls, and work practice norms, they felt threatened by the ongoing active maintenance work of the other (Brown et al, 2005). In particular, maintenance work became political for RD, as it demonized any actions that countered its market-based beliefs and insisted on policing of regulatory behaviors that affected it (Bachrach and Lawler, 1980; Hardy and Clegg, 1996). For its part, DD felt that the regulatory logic was threatened by the ongoing maintenance of the market logic. As it had the legitimacy of the regulatory logic to protect their work practices and norms, it was able to resort to different political tactics (Bachrach and Lawler, 1980). It did not confront RD but rather engaged in further disruption work, invalidating RD's claims and norms from a regulatory perspective (Hardy and Clegg, 1996).

In the face of this disruption and unable to preserve its own logic through maintenance work, RD engaged in politically-motivated creation work, attempting to minimize damage to its market logic by defining the appropriate supplier practices that it required of DD under the regulatory logic. This largely political attribution of meaning to the regulatory logic was a first attempt by actors working within the market logic to create the regulatory logic in relation to their own logic. Summary Finding 3: We thus see how, in pluralistic contexts, maintenance work can not only escalate conflict between contradictory logics but also generate other forms of institutional work, as actors engage in the political work of disrupting or creating the opposing logic in relation to their own interests.

In phase 4, following stronger intervention from $\mathrm{CC}$ and the $\mathrm{CEOs,}$ and more opportunities for inter-working, both sides began to actively create the other logic in relation to their own. In particular, they began to define the other logic as it impacted upon their own rule systems and, rather than dismissing or counteracting them, to consider how they might cope with these impacts within their own beliefs and practices. This was an important stage in shifting away from direct conflict, as it provided a basis for mutual adjustment between actors 
Jarzabkowski, P., Matthiesen, J.K., \& A. Van de Ven. 2009. 'Doing which work? A practice approach to institutional pluralism.' In Lawrence T., Leca, B. and R. Suddaby. (Eds) Institutional Work: Actors and Agency in Institutional Studies of Organizations. Cambridge, UK: Cambridge University Press

working within different logics (Kraatz and Block, 2007). However the act of relating to another logic was also innately threatening, such that active maintenance work had to continue at the same time. During this phase, $\mathrm{CC}$ began to create the regulatory logic in relation to the market logic in its external relationships with the Regulator. This was politically necessary in order for it to advocate commitment to the regulatory logic whilst attempting to contain the extent of its potential damage to the market logic. Summary Finding 4: We thus see that in pluralistic contexts, institutional creation work may provide grounds for actors working within different logics to relate to each other. Such relational creation work will also entail further maintenance work, as actors police their own beliefs and practices to prevent consideration of the other from diluting their own logic.

In Phase 5, creation of the other logic was increasingly absorbed into the work practices of each group as they maintained their own logic. Thus, maintenance work included policing of the potential impacts that each side's beliefs and practices might have upon the other. This in no way entailed a blending of the two logics, which remained discrete and intact, but did involve some changes in work practices to accommodate the other, such as accepting greater lead times, acknowledging operational interdependence, and more rapidly escalating points of conflict for arbitration. These changes were accompanied by fierce maintenance of the own logic, policing beliefs and norms, and actively re-embedding work practices in order to ensure that interaction did not damage the own logic. This process involved some compromises, not in the foundations of the logics but in their operationalization, as regulatory deadlines were delayed in order to ensure that minimum levels of customer service could be maintained, whilst volunteering financial penalties to support this compromise. These compromises may be seen as political acts of mutual adjustment in order to maintain pluralistic logics and continue to function within the principles of each (Lindblom, 1965). Summary Finding 5: We thus see that, in pluralistic 
Jarzabkowski, P., Matthiesen, J.K., \& A. Van de Ven. 2009. 'Doing which work? A practice approach to institutional pluralism.' In Lawrence T., Leca, B. and R. Suddaby. (Eds) Institutional Work: Actors and Agency in Institutional Studies of Organizations. Cambridge, UK: Cambridge University Press

contexts, maintenance work entails both active maintenance of the own logic and also maintenance of its relationship with the other logic. In this way, actors can mutually adjust to each other, whilst reinforcing and maintaining their own beliefs and practices. Such mutual adjustments may entail political compromises over deadlines or other events to enable action without constituting a fundamental shift in either logic.

\section{CONCLUSIONS AND IMPLICATIONS}

The practice approach taken in this study has provided a lens for understanding how pluralistic institutional logics are realized within the interactions between organizational members. It is in these interactions that institutional work occurs, reproducing or modifying existing institutions, emerging new institutions and disrupting old ones. The findings discussed above have provided the following important insights into institutional work and institutional pluralism.

First, our findings illustrate that, in the context of institutional pluralism, institutional maintenance involves ongoing active work. Institutional maintenance has been a neglected topic of study because institutional persistence is taken-for-granted (Lawrence and Suddaby, 2006; Scott, 2001). The various types of agency, practical, discursive, iterative and projective, (Clegg, 1989; Emirbayer and Mische, 1998; Giddens, 1984) involved in the maintenance of institutions have thus been overlooked. Lawrence and Suddaby (2006) propose that agency and active maintenance work will be heightened during times of upheaval. Our study indicates that the continuous threat posed by other logics provokes active maintenance work as part of the ongoing practical-evaluative agency involved in coping with pluralistic logics (Emirbayer and Mische, 1998; Jarzabkowski, 2005). Our findings suggest that in pluralistic contexts institutional maintenance occurs as a pattern of move and counter-move, as actors working within different logics respond to acts of maintenance by others. In order to maintain their own logics, different actors engaged in other forms of politically-motivated institutional 
Jarzabkowski, P., Matthiesen, J.K., \& A. Van de Ven. 2009. 'Doing which work? A practice approach to institutional pluralism.' In Lawrence T., Leca, B. and R. Suddaby. (Eds) Institutional Work: Actors and Agency in Institutional Studies of Organizations. Cambridge, UK: Cambridge University Press

work, either disrupting the other logic or creating it in relation to their own interests. Thus, we elaborate Lawrence and Suddaby's (2006) concept of institutional maintenance by showing that, in pluralistic contexts, maintenance work is not an occasional activity but an ongoing, politicized activity of response and counter response.

Second, our findings elaborate the concept of institutional maintenance by showing that, in pluralistic contexts, maintenance also involves acts of creation and disruption. That is, in order to maintain their own logics, different actors engaged in political acts of either disrupting the other logic or creating it in relation to their own interests. Active maintenance of co-existing logics within pluralistic contexts thus spills over into creative work and disruptive work

Third, our findings on how actors create another logic in relation to their own, further elaborate our understanding of institutional creation. While creation is typically an act of emerging a new institution (Lawrence and Suddaby, 2006), in the context of institutional pluralism, creation may be a political act used to establish a contradictory logic in relation to one's own interests, as shown by RD in Phase 3. However, as shown by both divisions and the $\mathrm{CC}$ in Phase 4, creation may also be a pragmatic act that enables actors working within contradictory logics to find ways of considering the other within the principles of their own rule systems. Creation work may thus occur not only to generate a new institution but also to allow actors working within existing institutions to create 'space' for other, contradictory logics to coexist with their own.

Fourth, our findings illuminate our understanding of institutional pluralism by showing how pluralistic institutions are realized within the actions and interactions of actors within organizations. The first pattern of institutional maintenance that we found in Phases 2 and 3, involving move and counter-move, indicate how actors can escalate conflict between institutions. Such moves lead to stalemate, as both institutions are legitimate such that neither 
Jarzabkowski, P., Matthiesen, J.K., \& A. Van de Ven. 2009. 'Doing which work? A practice approach to institutional pluralism.' In Lawrence T., Leca, B. and R. Suddaby. (Eds) Institutional Work: Actors and Agency in Institutional Studies of Organizations. Cambridge, UK: Cambridge University Press

side may 'win' these direct conflict games (Hargraves and Van de Ven, 2006; Jarzabkowski and Fenton, 2006; Kraatz and Block, 2007; Seo et al, 2004; Werner and Baxter, 1994). By contrast, the second pattern of creating and maintaining the other logic in relation to the own logic, found in Phases 4 and 5, provides the basis for mutual adjustment between logics. As Kraatz and Block (2007) suggest, this type of balancing of tensions in an ongoing and uneasy truce, is one way that organizations and their actors may learn to cope with coexistent and competing logics (Werner and Baxter, 1994). Mutual adjustment between logics is a political means by which organizations and their actors may cope with institutional pluralism (Lindblom, 1965).

Fifth, we found that particular work practices that emerged in Phases 4 and 5 enabled mutual adjustment, such as intensive and frequent inter-working between actors working within different logics, active hierarchical intervention and arbitration by authority figures, such as CEOs, and clear escalation mechanisms for coping with conflict. These findings suggest that institutional pluralism may be managed through organizational governance mechanisms (Kraatz and Block, 2007; Lawrence and Lorsch, 1971; Selznick, 1951). Further research might elicit those governance mechanisms that best enable actors to cope with and negate the conflict occasioned by pluralistic logics.

Finally, our findings on the creation and maintenance of other logics in relation to the own logic indicates that pluralistic logics are interdependent and relational. That is, in order for one logic to exist, the other must also exist. In particular, the external advocacy work undertaken by $\mathrm{CC}$ to demonstrate the importance of attending to the regulatory logic whilst ensuring the maintenance of the market logic suggests an intriguing relationship. Without a market, there would be no need for a regulatory logic. The regulatory logic exists to enable a freely competitive market by curbing the competitive excesses of that market, such as monopoly. While our findings are too tentative to draw strong conclusions, they indicate 
Jarzabkowski, P., Matthiesen, J.K., \& A. Van de Ven. 2009. 'Doing which work? A practice approach to institutional pluralism.' In Lawrence T., Leca, B. and R. Suddaby. (Eds) Institutional Work: Actors and Agency in Institutional Studies of Organizations. Cambridge, UK: Cambridge University Press

grounds for future research into the relational and interdependent features of institutional pluralism, in which competing logics might be seen as part of a greater system of institutional interactions (Kraatz and Block, 2007; Selznick, 1951).

In summary, this chapter has shown that, under conditions of institutional pluralism, actors must continuously maintain opposing institutional logics, which also requires them to engage in the politicized work of creating their own institutional logic and disrupting the opposing logic. The practice approach taken here has illuminated the nature of different types of institutional work and the interdependencies between these types of work, in the context of pluralistic institutional logics. Our study shows the processes and practices through which organizations and the actors within them cope with tensions between pluralistic logics over time.

\section{REFERENCES}

Archer, M. (1995). Realist Social Theory: The Morphogenetic Approach. Cambridge: Cambridge University Press.

Bacharach, S.B. and Lawler, E.J. (1980). Power and politics in organizations: The social psychology of conflict, coalitions, and bargaining. SF, CA: Jossey-Bass Inc.

Barley, S. \& Tolbert, P. 1997. Institutionalization and structuration: Studying the links between action and institution. Organization Studies 18.1: 93-117.

Barley, S. 1986. Technology as an occasion for structuring: Evidence from observations of CT scanners and the social order of radiography departments. Administrative Science Quarterly, 31.1: 78-109.

Bohman, J. (1999). 'Practical reason and cultural constraint: agency in Bourdieu's theory of practice'. In Shusterman, R. (Ed.), Bourdieu: A Critical Reader. Oxford: Blackwell, $128-52$.

Bourdieu, P. 1990. The logic of practice. Cambridge, UK: Polity Press.

Brown, G., T.B. Lawrence, and S.L. Robinson. 2005. Territoriality in organizations. Academy of Management Review, 30(3), 577-594.

Clark, P. 2000. Organisations in action: Competition between contexts. London, UK: Routledge. 
Jarzabkowski, P., Matthiesen, J.K., \& A. Van de Ven. 2009. 'Doing which work? A practice approach to institutional pluralism.' In Lawrence T., Leca, B. and R. Suddaby. (Eds) Institutional Work: Actors and Agency in Institutional Studies of Organizations. Cambridge, UK: Cambridge University Press

Denis, J-L; Langley, A; and Rouleau, L. 2007. Strategizing in pluralistic contexts: Rethinking theoretical frames. Human Relations, Forthcoming

DiMaggio, P. J., \& Powell, W. W. 1983. The iron cage revisited: Institutional isomorphism and collective rationality in organizational fields. American Sociological Review, 48: 147-160.

Eisenhardt K.1989. Building theories from case study research. Academy of Management Review, 14, 4, 532-50

Evered R., \& Louis M.R., 1981, Alternative perspectives in the organizational sciences: 'Inquiry from the inside' and 'Inquiry from the outside'. Academy of Management Review, 6.3: 385-396.

Friedland, R. \& Alford, R. R. 1991. Bringing society back in: Symbols, practices, and institutional contradictions. In W. W. Powell \& P. J. DiMaggio (eds.), The new institutionalism in organizational analysis: 232-263, Chicago: University of Chicago Press.

Friedman, M. 1970. "The Social Responsibility of Business Is to Increase Its Profits," New York Times Magazine (1 September 1970).

Geertz, C. (1973) The Interpretation of Cultures. New York: Basic Books.

Giddens, A. 1984. The Constitution of Society. Cambridge, UK: Polity Press.

Glynn, M. and Lounsbury, M. 2005. From the Critics' Corner: Logic Blending, Discursive Change and Authenticity in a Cultural Production System. Journal of Management Studies, 42:5: 1031-55.

Greenwood, R. \& Hinings, C.R. 1996. Understanding radical organizational change: Bringing together the old and the new institutionalism. Academy of Management Review, 21: 1022-1054.

Greenwood, R., Suddaby, R. \& Hinings, C. R. 2002. Theorizing change: The role of professional associations in the transformation of institutionalized fields. Academy of Management Journal, 45: 58-80.

Hargraves, T. and Van de Ven, A. 2006. A collective action model of institutional innovation Academy of Management Review, 31.4: 864-888.

Holm, P. 1995. The dynamics of institutionalization: Transformation processes in Norwegian fisheries. Administrative Science Quarterly, 40: 398-422

Hopwood, A. and Miller, P. (Eds.) (1994) Accounting as Social and Institutional Practice. Cambridge: Cambridge University Press.

Jarzabkowski, P. 2004. 'Strategy as practice: Recursiveness, adaptation and practices-in-use.' Organization Studies, 25.4: 529-560. 
Jarzabkowski, P., Matthiesen, J.K., \& A. Van de Ven. 2009. 'Doing which work? A practice approach to institutional pluralism.' In Lawrence T., Leca, B. and R. Suddaby. (Eds) Institutional Work: Actors and Agency in Institutional Studies of Organizations. Cambridge, UK: Cambridge University Press

Jarzabkowski, P. 2005. Strategy as Practice: An Activity-Based View. UK: Sage.

Jarzabkowski, P., Balogun, J and D. Seidl. 2007. 'Strategizing: The challenges of a practice perspective'. Human Relations, 60.1: 5-27.

Jarzabkowski, P. Matthiesen, J. and A. Van de Ven. 2008. 'Doing which work? A practice approach to institutional pluralism'. Aston Business School Working Paper: ISBNNo: 978-1-85449-727-7

Jepperson, R. L. 1991. Institutions, institutional effects, and institutionalism. In W. W. Powell \& P. J. DiMaggio (Eds.) The new institutionalism in organizational analysis: 143-163. Chicago: University of Chicago Press.

Kraatz, M. and Block, E. 2007. 'Organizational Implications of Institutional Pluralism'. Forthcoming in The Handbook of Organizational Institutionalism, edited by Royston Greenwood, Christine Oliver, Kerstin Sahlin-Andersson and Roy Suddaby.

Langley, A. 1999. Strategies for theorizing from process data. Academy of Management Review, 24, 4, 691-710.

Lawrence, T. \& Suddaby, R. 2006. Institutions and Institutional Work. In Handbook of Organization Studies, $2^{\text {nd }}$ Edition, Thousand Oaks: Sage.

Lawrence, T. B., \& Phillips, N. 2004. From Moby Dick to Free Willy: Macro-cultural discourse and institutional entrepreneurship in emerging institutional fields. Organization, 11(5): 689-711.

Lincoln, Y.S. \& Guba, E.G. 1985. Naturalistic Inquiry. London: Sage.

Lindblom, C.E. (1965), The Intelligence of Democracy: Decision Making through Mutual Adjustment

Lounsbury, M. 2007. A tale of two cities: Competing logics and practice variation in the professionalizing of mutual funds. Academy of Management Journal, 50.2: 280-307.

Meyer, J. W., \& Rowan, B. 1977. Institutionalized organizations: Formal structure as myth and ceremony. American Journal of Sociology, 83: 340-363.

Miles, M. \& Hubermann, A. 1994. An Expanded Sourcebook; Qualitative Data Analysis. London: Sage.

Oliver, C. 1991. Strategic responses to institutional processes. Academy of Management Review, 16: 145-179.

Orlikowski W. 2002. "Knowing in Practice: Enacting a Collective Capability in Distributive Organizing.” Organization Science, 13.3:249-273.

Orlikowski, W. 1992. The Duality of Technology: Rethinking the Concept of Technology in Organizations. Organization Science, 3.3: 398-427. 
Jarzabkowski, P., Matthiesen, J.K., \& A. Van de Ven. 2009. 'Doing which work? A practice approach to institutional pluralism.' In Lawrence T., Leca, B. and R. Suddaby. (Eds) Institutional Work: Actors and Agency in Institutional Studies of Organizations. Cambridge, UK: Cambridge University Press

Ortner, S. (1984). Theory in anthropology since the sixties. Comparative Studies in Society and History, 26: 126-166.

Pettigrew, A. 1990. Longitudinal field research on change theory and practice. Organization Science, 1, 3, 267-92.

Poole, M.S. \& Van de Ven, A.H. 1989. Using paradox to build management and organization theories, Academy of Management Review, 14, 4: 562-578.

Reckwitz, A. (2002) 'Towards a theory of social practice: A development in cultural theorizing'. European Journal of Social Theory, 5, 2: 243-63.

Russo, M. V. 2001. Institutions, exchange relations and the emergence of new fields: Regulatory policies and independent power production in America, 1978-1992. Administrative Science Quarterly, 46: 57-86

Schatzki, T.R., Cetina, K.K. and v. Savigny, E. (2001). The Practice Turn in Contemporary Theory. London: Routledge.

Scott, W. R. 1995. Institutions and Organizations: Theory and Research. Sage Publications, London

Scott, W. R. 2001. Institutions and organizations, 2nd Edition. Thousand Oaks, CA: Sage.

Selznick, P. 1949. TVA and the grass roots. Berkeley: University of California Press.

Seo, M., \& Creed, W. E. D. 2002. Institutional contradictions, praxis, and institutional change: A dialectical perspective. Academy of Management Review, 27: 222-247.

Seo, M.G., Putnam, L.L. \& Bartunek, J.M. 2004. Dualities and Tensions of Planned Organizational Change, in M.S.Poole \& A.H. Van de Ven (eds.) Handbook of Organizational Change and Innovation, New York: Oxford Univ. Press, Chapter 4, pp. 73-107.

Sharratt D, Brigham BH and Brigham, M (2007). The utility of social obligations in the UK energy industry. Journal of Management Studies, 44.8

Suddaby, R. \& R. Greenwood, 2005. Rhetorical strategies of legitimacy. Administrative Science Quarterly, 50: 35-67.

Sztompka, P. 1991. Society in action: The theory of social becoming. Cambridge, UK: Polity Press.

Townley, B. 2002. The role of competing rationalities in institutional change. Academy of Management Journal, 45: 163-179.

Tsoukas, H. and Chia, R. (2002) 'On organizational becoming: Rethinking organizational change'. Organization Science, 13, 5: 567-82 
Jarzabkowski, P., Matthiesen, J.K., \& A. Van de Ven. 2009. 'Doing which work? A practice approach to institutional pluralism.' In Lawrence T., Leca, B. and R. Suddaby. (Eds) Institutional Work: Actors and Agency in Institutional Studies of Organizations. Cambridge, UK: Cambridge University Press

Turner, S. (1994). The Social Theory of Practices. Cambridge, UK: Polity Press.

Van de Ven, A. 1992. Suggestions for studying strategy process: A research note. Strategic Management Journal 13: 169-88

Werner, C. M., \& Baxter, L. A. (1994). Temporal qualities of relationships: Organismic, Transactional, and Dialectical Views. In M. Knapp \& G. R. Miller (Eds.), Handbood of interpersonal communication (2nd ed., pp. 323-379). Thousand Oaks, CA: Sage

Whittington, R. 1992. "Putting Giddens into Action: Social Systems and Managerial Agency." Journal of Management Studies, 29, 6, 693-712.

Whittington, R. 2006. Completing the practice turn in strategy research. Organization Studies,.

Wilson, D. C. and Jarzabkowski, P. 2004 "Thinking and acting strategically: New challenges for interrogating strategy". European Management Review 1: 14-20

Yin, R. K. 1994. Case Study Research. London, UK: SAGE Publications. 
Table 1: Representative Examples of Market and Regulatory Logics of Action

Logic

Regulatory • "we don't compete with our customers anymore and all customers are equally good ... And there's

Logic no benefit to $D D$ in spending lots and lots of sales effort on one customer to the detriment of another. So our customers can sort that out for themselves, they can compete in the end user market (DD Middle Manager).

- Utilco RDs are our biggest customer still, without a doubt, so you have to watch the balance at an industry meeting; the sheer weight of their voice, we need to make sure we have equivalent ..." (DD Director).

- "What we don't want is for people to have to balance their Utilco versus DD hats; not a good thing. ... Whatever you do, don't not do what's right for $D D$. If you start doing things that are right for Utilco Group, phew you know" (DD regulation director)

- "Utilco could meet a lot of the Framework just by ticking the boxes but that wouldn't be in the spirit of it. So we need to meet the spirit of the Framework" (DD Reg'n Director)

- "with the Regulator we have to be pretty careful. That's where I think some of the spirit thing comes in because ... if we didn't, there is the potential that the regulator I think will come down pretty hard on you" (DD Product X manager).

- "as long as we're not charging anyone except $R D$, then we're not getting a complaint from anyone except $R D$, which is less of a problem [than industry complaints]" (DD manager in meeting)

- "the profit in RDs which are expected to have a good growth profile is key. That will support our share price more than the profit in $D D$. Share price is obviously ... well the major thing we have to take into consideration so if by doing this model we actually alter... if we move profit out of RDs and back up the value chain to the up-stream so to DD our share price could be affected" (Utilco Finance Director).

- "I presume shareholders would expect Utilco's wholly owned selling entity, RD and its wholly owned producer, $D D$, to act within the spirit of the law but also to the benefit of its shareholders" (RD2 Commercial Manager).

- "So our biggest challenge ... at the moment is the setting of customers' expectations ... The RD business model incurs losses for every second of customer time added." (RD manager)

- "RD is a big customer of $D D$; we would expect from any supplier that are part of purchase, would give us some advantage because that's the way the world works. That's the law of the world you know, that's how it works. And I expect that to be the same when I deal with DD. So a little start-up company who gives you know, DD $£ 10,000$ a year, should not have a better service than me who spend £10million a year" (RD2 Change Manager).

- "It goes against everything we've been indoctrinated with over all our years with Utilco ... It takes away our cutting edge over customer service" (RD2 operational manager)

- What do we owe them to shield them from that kind of pressure? They're dragging down the work we're trying to do, to grow our business" (RD Regulation manager)

\section{Logic of action}

- An equivalent or level playing field for all players is desirable in the marketplace

- DD's purpose is to supply the whole of industry in an equivalent way

- DD is totally independent from Utilco downstream businesses in its decision-making

- DD voluntarily complies with regulation and does not need to be coerced

- Do not accord advantage to Utilco downstream businesses, regardless of its commercial value to DD

- Utilco and RDs' concerns are of lower priority than regulatory or industry concerns

- Shareholder value and share price are our key concerns as a listed company

- Customer service is central to the Utilco value proposition and profitability

- As one of the largest players in the industry, Utilco RDs should be able to gain normal scale advantages in the market

- Regulation should not get in the way of profitability

- RD actions should benefit Utilco share price

- RD should protect customer service at all costs

- DD decisions should not be allowed to damage the RD business model 
Table 2: Approaches to Institutional Pluralism in Different Phases

\begin{tabular}{|c|c|c|c|}
\hline \multicolumn{4}{|c|}{ (Key: RL = Regulatory Logic; ML = Market Logic) } \\
\hline Phases & DD Institutional Work & RD Institutional Work & CC Institutional Work \\
\hline 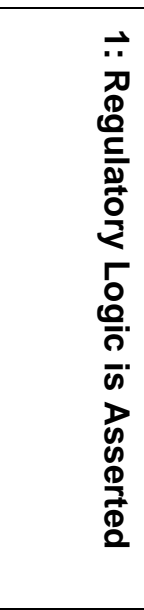 & $\begin{array}{l}\text { Disrupting ML: Physical separation \& } \\
\text { information-sharing barriers disconnects } \\
\text { rewards \& sanctions \& requires re-routing of } \\
\text { existing patterns of interaction. This } \\
\text { undermines assumptions \& beliefs about the } \\
\text { ML \& disassociates from the taken-for-granted } \\
\text { moral foundations of customer service. } \\
\text { Creating RL: Engage in largely political } \\
\text { creation work, defining to others the } \\
\text { boundaries for what constitutes proper } \\
\text { behaviour from a regulatory perspective. } \\
\text { Maintaining RL: Adherence to rule systems is } \\
\text { predominant, particularly policing own } \\
\text { behaviour \& embedding that in everyday } \\
\text { practices, such as independent working. }\end{array}$ & $\begin{array}{l}\text { Maintaining ML: Respond to attempted } \\
\text { disruption by DD as threats to the ML. Engage } \\
\text { in political acts of adherence, such as } \\
\text { appealing for greater policing of potential } \\
\text { threats from DD's behaviour. Such acts also } \\
\text { actively reconfirm and embed customer service } \\
\text { beliefs within own activities. }\end{array}$ & $\begin{array}{l}\text { Maintaining } \mathrm{RL} \text { : Adhere to rule systems that } \\
\text { support the } \mathrm{RL} \text {, such as supporting non- } \\
\text { engagement between the two divisions. This } \\
\text { implicitly disrupts the ML by failing to advocate } \\
\text { it. } \\
\text { Disrupting ML: Undermine assumptions about } \\
\text { work practices by suggesting that RD's } \\
\text { problems with Product } X \text { require it to find } \\
\text { different practices, rather than exercising } \\
\text { dependence on or blaming DD. }\end{array}$ \\
\hline 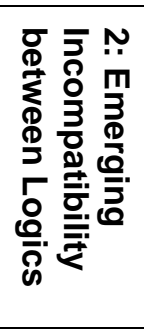 & $\begin{array}{l}\text { Maintaining RL: Establish practices for sharing } \\
\text { information with industry \& RD at the same } \\
\text { time. This enables it to adhere to the norms \& } \\
\text { rules of its own logic \& embed them within } \\
\text { everyday work practices. }\end{array}$ & $\begin{array}{l}\text { Maintaining ML: Reinforce beliefs in ML by } \\
\text { emphasizing and insisting on customer- } \\
\text { servicing work practices. Maintain own rule } \\
\text { systems by policing DD behaviour that is } \\
\text { inappropriate to these systems. Attempt } \\
\text { deterrence, by insisting that DD be accountable } \\
\text { for the damage to customer service that might } \\
\text { arise from its work practices. }\end{array}$ & $\begin{array}{l}\text { Maintaining } R L \text { : Attempt to enable both logics } \\
\text { by prioritizing regulatory objectives, whilst } \\
\text { emphasizing deterrents for not achieving SID. } \\
\text { While this reinforces the } R L \text { at a high level, it } \\
\text { does not pay attention to the complementary } \\
\text { work practices between RD \& DD, necessary } \\
\text { to achieve regulatory objectives }\end{array}$ \\
\hline 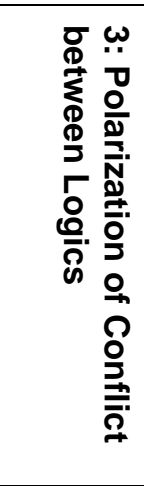 & $\begin{array}{l}\text { Maintaining RL: Adhere to own rule systems \& } \\
\text { further embed them in independent work } \\
\text { practices. Even where it considers the RD } \\
\text { position, it does so only within the conscious } \\
\text { adherence to its own rule systems, such as } \\
\text { engaging with industry. } \\
\text { Disrupting ML: Respond to RD's ML-based } \\
\text { problems by suggesting that RD's beliefs in } \\
\text { customer service no longer have legitimacy. }\end{array}$ & $\begin{array}{l}\text { Maintaining ML: Engage in increasingly active } \\
\text { maintenance work, including demonizing DD } \\
\text { for destroying customer service levels in the } \\
\text { entire industry. Police DD's anti-ML behaviour } \\
\text { and assert the rightness of its customer service } \\
\text { beliefs. } \\
\text { Creating RL in relation to ML: Engage in } \\
\text { political work, defining DD's position within the } \\
\text { market as one of supplier, and hence defining } \\
\text { those practices expected of a supplier from a } \\
\text { market perspective. The RL is thus defined in } \\
\text { relation to the ML. }\end{array}$ & $\begin{array}{l}\text { Maintaining } R L \text { : Attempt to balance the two } \\
\text { logics under a super-ordinate goal, that, by } \\
\text { default, adheres to the rule systems of the } R L \\
\text { and hence, does not actively maintain the ML. }\end{array}$ \\
\hline
\end{tabular}



Institutional Work: Actors and Agency in Institutional Studies of Organizations. Cambridge, UK: Cambridge University Press

\begin{tabular}{|c|c|c|c|}
\hline 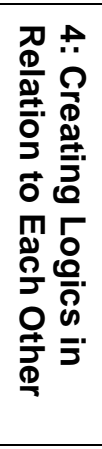 & $\begin{array}{l}\text { Creating ML in relation to RL: Some } \\
\text { reconfiguring of belief systems in order to } \\
\text { identify RD's ML-based problems as something } \\
\text { DD may take into account, within necessary } \\
\text { adherence to its own RL-based rule systems. } \\
\text { Maintaining RL: Adhere to own rule systems by } \\
\text { policing any potential ML-based threats to its } \\
\text { belief in equivalence. Reinforce own belief } \\
\text { systems by embedding separation of DD work } \\
\text { practices from Utilco policing or coercion. }\end{array}$ & $\begin{array}{l}\text { Creating } R L \text { in relation to } M L \text { : Some } \\
\text { reconfiguring of belief systems in order to } \\
\text { identify barriers created by } R L \text { as legitimate } \\
\text { and requiring some changes in work practices } \\
\text { within } R D \text {, such as new ways of } \\
\text { communicating with } D D \text { through industry fora. } \\
\text { Maintaining ML: Reinforce own belief systems, } \\
\text { by insisting that } R D \text { practices are the norm for } \\
\text { large-scale operators within a market. }\end{array}$ & $\begin{array}{l}\text { Maintaining RL \& ML: Reinforce belief in both } \\
\text { logics and insist on adherence to the rule } \\
\text { systems and beliefs of both. Engage in greater } \\
\text { policing and enabling of both logics by } \\
\text { instituting weekly CEO meetings. } \\
\text { Creating RL in relation to ML: Engage in } \\
\text { political work of advocacy to external } \\
\text { audiences, in order to demonstrate that Utilco } \\
\text { is committed to acting sensibly on RL, } \\
\text { accepting financial regulatory penalties in order } \\
\text { to avoid destroying ML. }\end{array}$ \\
\hline 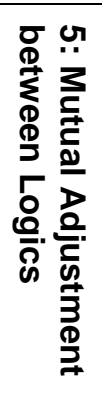 & $\begin{array}{l}\text { Maintaining } R L \text { in relation to } M L \text { : Ongoing } \\
\text { process of maintaining } R L \text { in relation to } M L \text {. } \\
\text { This enables them to take account of } \& \text { create } \\
\text { some space to tolerate demands of } M L \text {, whilst } \\
\text { engaging in active countering, such as policing } \\
\text { potential ML-based threats to } R L \text { and } \\
\text { embedding } R L \text { within own work practices. This } \\
\text { includes some disrupting type work, such as } \\
\text { invalidating } M L \text { practices where they are } \\
\text { threatening. }\end{array}$ & $\begin{array}{l}\text { Maintaining } M L \text { in relation to RL: Ongoing } \\
\text { process of maintaining } M L \text { in relation to RL. } \\
\text { This enables them to take account of } \& \text { create } \\
\text { some space to tolerate } R L \text {, whilst engaging in } \\
\text { active countering, such as asserting the } \\
\text { 'rightness' of their service differentiation, where } \\
\text { threat to } R L \text { is perceived. }\end{array}$ & $\begin{array}{l}\text { Creating } R L \text { in relation to } M L \text { : Ongoing political } \\
\text { work of advocacy to external audiences, in } \\
\text { order to ensure that } R L \text { can be met, with } \\
\text { compromises that also enable Utilco to } \\
\text { maintain the } M L \text {. } \\
\text { Maintaining } R L \& M L: \text { Engage in active } \\
\text { reinforcing of and adherence to each logic, } \\
\text { which involves mutual adjustment between } \\
\text { divisions, until Product } X \text { is fully attained. }\end{array}$ \\
\hline
\end{tabular}

